\title{
Neural tube defects in rural Ireland
}

\author{
M J O'DOWD, K CONNOLLY, AND A RYAN \\ Portiuncula Hospital, Ballinasloe, Co Galway, Ireland
}

SUMmary The incidence of neural tube defects in a rural area of the west of Ireland from 1974 to 1985 was 2.96 per 1000 . The prevalence was unchanged during the 11 years. When compared with a control group there was no increased incidence of anaemia in mothers of affected infants.

The incidence of neural tube defects in Ireland, as in most countries, is falling. Four Dublin maternity hospitals reported an incidence of 6.6 per 1000 from 1970 to $1973^{1}$ compared with an incidence of 3.98 per 1000 from the same area 10 years later. ${ }^{2}$ This fall in incidence has not been influenced by induced abortions as pregnancy termination is not carried out in Dublin. A similar fall in incidence has occurred in other countries. ${ }^{3}$

The incidence of neural tube defect is higher in Ireland than most other countries, even allowing for the impact of antenatal screening and pregnancy termination. In Strasbourg from 1979 to 1983 the rate, including induced abortions, was 1.02 per 1000 compared with a rate in Dublin over the same period of 3.98 per $1000 .^{2}$

It is unknown whether the incidence of neural tube defects is similar in all areas of Ireland and whether the prevalence is falling in all areas. This survey aimed to report the incidence of neural tube defects in an area of rural Ireland from 1974 to 1985 inclusive; to see if there was a change in the prevalence; and to determine if anaemia was more common at the first antenatal visit in mothers who subsequently delivered an infant with a neural tube defect.

\section{Patients and methods}

Portiuncula Hospital serves a mainly rural popula- tion in the west of Ireland. This retrospective study was based on records of all infants over 28 weeks' gestation delivered in the hospital during the years 1974 to 1985 inclusive. All available data, including maternity annual reports, maternity charts, delivery registers, and baby unit records, were examined to identify those infants born with neural tube defects. Cases of neural tube defects were defined as infants with anencephaly, spina bifida aperta, or encephalocoele.

\section{Results}

During the 11 years there were 22272 infants born with a gestational age of over 28 weeks. A neural tube defect occurred in 66 infants-an incidence of 2.96 per 1000 births. The yearly incidence of neural tube defects (Table) was analysed using the Wilcoxon rank sum test, taking into account four tied ranks. This showed no significant change in incidence over the 11 years $(\lambda=0.003)$

Of the 66 infants, $32(49 \%)$ had spina bifida, 28 $(42 \%)$ had anencephaly, and six $(9 \%)$ had an encephalocoele.

The overall perinatal mortality was $67 \%$. Of the 38 infants with spina bifida or an encephalocoele, 16 $(42 \%)$ were perinatal deaths, six $(16 \%)$ were late deaths, and $16(42 \%)$ are still alive. Nine of the survivors are normal or have mild handicap and seven have moderate or severe handicap.

We compared haemoglobin concentrations at the first antenatal visit in mothers of infants with neural tube defects with the next 66 mothers of similar age, parity, and social class who delivered a normal infant. Neither group of patients was receiving periconceptual vitamin or iron supplements.

Eleven of the group with neural tube defects had haemoglobin concentration of less than $11 \mathrm{~g} / \mathrm{dl}$ compared with only three of the control group. The

Table Yearly number and incidence per 1000 of cases of neural tube defects

\begin{tabular}{|c|c|c|c|c|c|c|c|c|c|c|c|}
\hline & \multicolumn{11}{|l|}{ Year } \\
\hline & 1975 & 1976 & 1977 & 1978 & 1979 & 1980 & 1981 & 1982 & 1983 & 1984 & 1985 \\
\hline Deliveries & 1349 & 1518 & 1608 & 1588 & 1776 & 2126 & 2302 & 2444 & 2364 & 2482 & 2428 \\
\hline No with neural tube defects & 7 & 4 & 5 & 4 & 1 & 10 & 3 & 4 & 4 & 13 & 11 \\
\hline Incidence (per 1000) & $5 \cdot 2$ & $2 \cdot 6$ & $3 \cdot 1$ & $2 \cdot 5$ & $0 \cdot 6$ & 4.7 & $1 \cdot 3$ & 1.6 & $1 \cdot 7$ & $5 \cdot 2$ & $4 \cdot 5$ \\
\hline
\end{tabular}


mean (SD) haemoglobin of $11.6(3.3) \mathrm{g} / \mathrm{dl}$ in the group with neural tube defects compared with 11.8 $(2 \cdot 7) \mathrm{g} / \mathrm{dl}$ in the control group and was not significantly different $(t=0 \cdot 38, p=0 \cdot 7)$.

\section{Discussion}

There is a significantly higher incidence of neural tube defect in the main population centres on the east coast of Ireland. The incidence in Dublin is 3.98 per 1000 and in Belfast is $3 \cdot 86$ per $1000,{ }^{2}$ and both are higher than our own incidence of 2.96 per 1000 . It may be that our lower rate reflects differences in nutritional state and social structure. Unlike reports from other areas, we have not noted a change in the incidence of neural tube defect over the 11 years.

A possible link between nutritional factors, particularly folate deficiency, and neural tube defect was first reported in $1965 .{ }^{4}$ Smithells et al suggested periconceptual multivitamin supplementation as a method of reducing the incidence of neural tube defects. ${ }^{5}$ In our study there were no significant differences in haemoglobin values at the first antenatal visit between mothers of children with neural tube defects and a control mothers. We have no data, however, for folate or vitamin $\mathrm{B}_{12}$ concentrations.

We thank Vida Tansey for statistical help.

\section{References}

1 McCarthy PA, Dalrymple IJ, Duignan NM, et al. Recurrence rates of neural tube defects in Dublin maternity hospital. Ir Med J 1983;76:78-9

2 De Wals P, Lechat MF, eds. Surveillance of congenital anomalies, years 1980-1983. Brussels: Catholic University of Louvain, 1986. (Eurocat report 1.)

${ }^{3}$ Stein SC, Feldman JG, Friedlander M, Klein RJ. Is myelomeningocele a disappearing disease? Pediatrics 1982;69:511-4.

4 Hibbard ED, Smithells RW. Folic acid metabolism and human embryopathy, Lancet 1965;i:1254-6.

5 Smithells RW, Sheppard S, Schorah CJ, et al. Possible prevention of neural tube defects by periconceptual vitamin supplementation. Lancet 1980;i:339-40.

Correspondence to $\operatorname{Dr}$ M J O'Dowd, Portiuncula Hospital, Ballinasloe, Co Galway, Ireland.

Received 29 October 1986

\title{
Anti-rotavirus antibody in cerebrospinal fluid
}

\author{
H USHIJIMA, K ARAKI, T ABE, AND T SHINOZAKI \\ Department of Pediatrics, Teikyo University School of Medicine, Tokyo, Japan
}

SUMmaRY Ten infants with benign convulsions associated with rotavirus gastroenteritis had no specific antibodies in cerebrospinal fluid by enzyme linked immunosorbent assay (ELISA). On the other hand, eight of 173 patients with other neurological diseases had specific IgG, IgA, or IgM antibodies. The reason for positive ELISA results is discussed.

We have reported a case of suspected rotavirus encephalitis detecting anti-rotavirus antibody in cerebrospinal fluid (CSF) by enzyme linked immunosorbent assay (ELISA) in this journal. ${ }^{1} \mathrm{We}$ further examined anti-rotavirus antibody in CSF specimens from other cases with neurological involvement to discover the relation between rotavirus and diseases of the central nervous system.

\section{Patients and methods}

Fourteen CSF specimens from 10 infants with benign convulsions associated with rotavirus gastroenteritis and $230 \mathrm{CSF}$ specimens from 173 patients with other neurological diseases were examined for anti-rotavirus antibody. The specimens were centrifuged and supernatant stored at $-20^{\circ} \mathrm{C}$ until tested.

ELISA for antibody measurement was assayed using purified human rotavirus (serotype 4 , subgroup II) and affinity purified peroxidase labelled goat antihuman $\operatorname{IgG}, \operatorname{IgA}$, and IgM antibodies. ${ }^{12}$

Antirotavirus antibody in CSF was considered to be positive when the optic density of an examined 10 -fold diluted CSF specimen was more than that of 1000 -fold diluted positive control serum, because (1) if serum anti-rotavirus antibody penetrated passively to CSF the value in CSF was less than 100 -fold that in serum, and (2) the mean optic density plus two standard deviations of negative samples was almost the same optic density of the 1000-fold diluted positive control serum. Positive samples were examined in duplicate and in a blocking assay. 